\title{
Growth and age class distribution of Pterygophora californica (Phaeophyta)
}

\author{
R. E. De Wreede \\ Department of Botany, The University of British Columbia, Vancouver, B.C. V6T 2B1, Canada
}

\begin{abstract}
Pterygophora californica Ruprecht (Laminariales, Phaeophyta) is a perennial brown alga often found in the upper subtidal zone of oceanic coastal sites of British Columbia, Canada. The phenology and age class distribution of $P$. californica was studied for over 2 yr at 3 study sites in Barkley Sound, British Columbia. Maximum elongation of stipes, apical blades, and sporophylls generally occurred from (Feb) Mar to Jun, and the minimum from Oct to Dec (Jan). Stipe elongation varies within and among sites (5.4 to $18.2 \mathrm{~cm} \mathrm{yr}^{-1}$ ). Sporophylls made up $50 \%$ of the total dry weight (minus holdfast) but the apical blade never exceeded $7 \%$. Stipe rings formed once a year, and this information was used to estimate age class distributions. At each study site there were very few young $(<2 \mathrm{yr})$ and old $(>9 \mathrm{yr})$ individuals. Based on age class distribution and other observations, the pattern of settlement and survival appears to be similar at the 3 sites. An existing population is decimated (probably by a combination of sea urchins and storms), followed by relatively high annual recruitment and survival rates for 3 to $4 \mathrm{yr}$. Subsequently there is little new recruitment until the adult plants once more disappear.
\end{abstract}

\section{INTRODUCTION}

Pterygophora californica Ruprecht is a perennial brown alga (Laminariales, Alariaceae) often found in British Columbia, Canada, in the upper subtidal zone of coastal sites; in contrast, in California, the species is most abundant at depths of 6 to $20 \mathrm{~m}$. In British Columbia it may exist in nearly monospecific stands or grow intermixed with Laminaria setchellii Silva, Eisenia arborea Areschoug or, more rarely, Macrocystis integrifolia Bory and Nereocystis luetkeana (Mert.) Post. \& Rupr. One common herbivore in or near such sites is the red urchin Strongylocentrotus franciscanus Agassiz.

Pterygophora californica has long been known, to have concentric rings in the stipe (Ruprecht, 1848). MacMillan (1902) concluded that these rings were formed by alternating periods of slow (darker tissue) and rapid (lighter tissue) growth and found them similar to the annual rings of trees. Frye (1918) reviewed the literature on rings in $P$. californica and, using 3 separate lines of empirical evidence, concluded that in his specimens 1 dark and 1 light ring each were formed annually. Other authors (reviewed by Novaczek, 1981), studying different kelp species with stipe rings, have also concluded that such rings were formed annually.

Once the periodicity of stipe ring formation is known, a tool is available for studying both the age structure of a population and age associated phenomena. In general, few such studies have been performed on algae, and none on Pterygophora californica. Kain (1971) reported on the age structure of populations of Laminaria hyperborea (Gunn.) Fosl., Gunnill (1980) on Pelvetia fastigiata (J. Ag.) De Toni, Coyer and Zaugg-Haglund (1982) on Pelagophycus porra (Lam.) Setch., and Novaczek (1981) on Ecklonia radiata (C. Ag.) J. Ag. No studies have been published on in situ growth of $P$. californica, apart from the casual observations by some of the above named authors.

In this paper I report on the seasonal pattern of stipe growth, biomass allocation, rates of stipe-ring formation, and age class distributions of Pterygophora californica. Kain (1971) and Novaczek (1981) stressed that growth of the species they studied was strongly influenced by environment; nevertheless, each concluded that rings form annually. However, there is no a priori reason to assume either annual rings for different species, or that the same species will have annual rings at all sites.

\section{METHODS}

Study sites (Fig. 1) are located in Barkley Sound, on the west coast of Vancouver Island, British Columbia, 


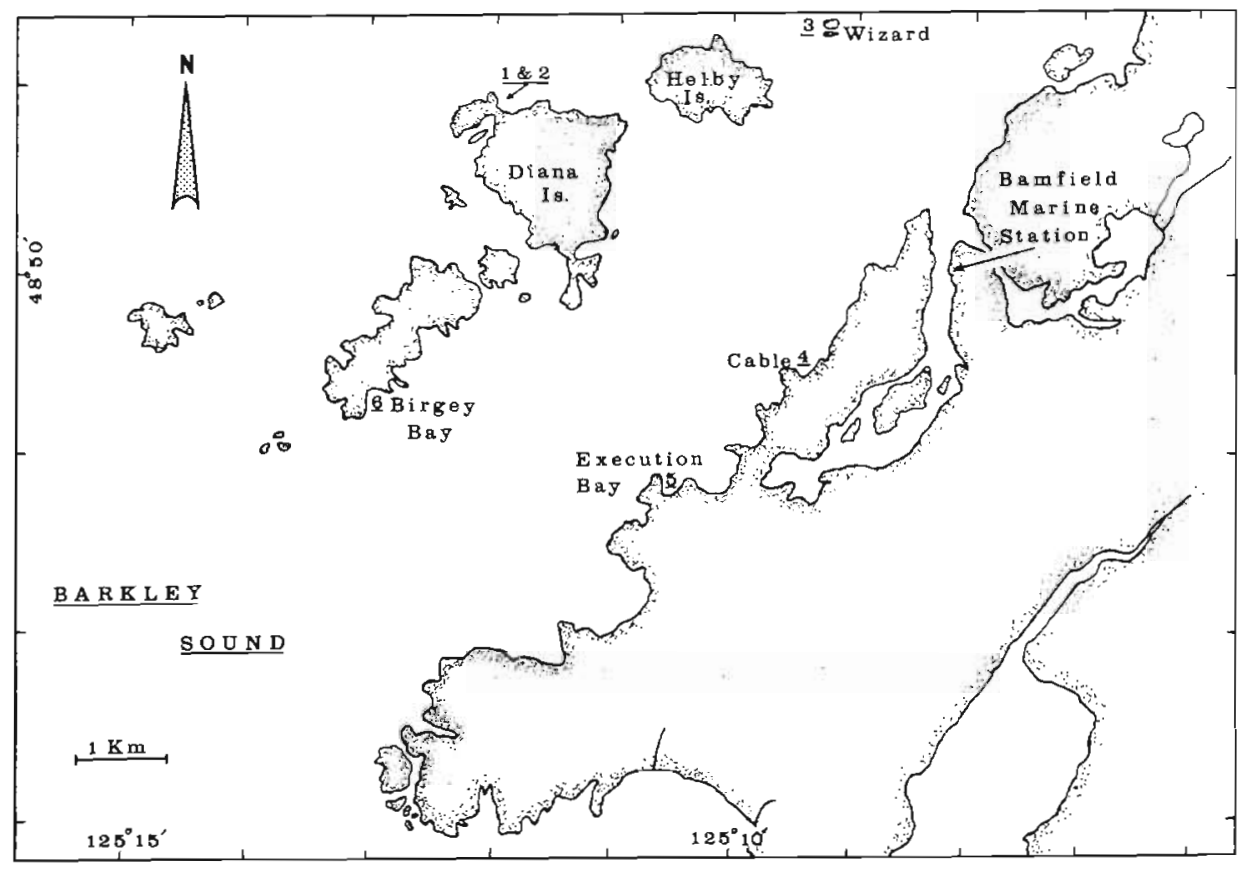

Fig. 1. Map of study sites in Barkley Sound, British Columbia, Canada

Canada. Three sites, Diana Island shallow (Site 1), Diana Island deep (Site 2) and Wizard Rocks (Site 3), were studied in detail. Three others, Cable Beach (Site 4), Execution Bay (Site 5), and Birgey Bay (Site 6), were used in one comparative study of ring number and stipe length. All sites are subtidal and all work was done using SCUBA. An exposure gradient to prevailing wind and waves exists from Sites 1 and 2 (least) to Site 6 (greatest).

In each of Sites 1 to 3 a minimum of 30 Pterygophora californica plants were used to measure holdfast depth in relation to tide level; these measurements were then averaged to obtain the mean depth for each study site. Depth was measured using a diver's Bourdon Gauge and a watch, and the data were referred to the appropriate Canadian Tide and Current Tables (Canadian Hydrographic Service 1982) for conversion to Chart Datum.

At each of Sites 1 to 3 a minimum of 50 plants of mixed size classes were labelled along the upper portion of the stipe using various tagging devices. Dymotape attached to locking 'zip-tabs', 'Tagger-tails' (C) Monarch Marking) attached with a Monarch Marking label gun (Model MD 1310), and variations of these were used to identify individual plants. Stipe length (distance from the base of the stipe to the stipe/blade transition zone), signs of sea urchin grazing, and presence of sporangia, were measured 6 or more times per year for each labelled plant. At Sites 1 and 2,50 additional plants were double-tagged to monitor tag attrition.

Stipe growth rate of young plants was calculated separately for several populations. One estimate was obtained from plants harvested from ropes placed in the water near the study sites on Dec 9, 1981. McKay (1933) reports on maturation rates of Pterygophora californica gametophytes (in culture) and, using these data, I estimated that $12 \mathrm{wk}$ would elapse from spore settlement to formation of the new sporophyte. This enabled me to calculate the stipe elongation rates of plants measured on May 5, 1982. At each of the 3 study sites an estimate was obtained by calculating the elongation rate for tagged plants less than $30 \mathrm{~cm}$ tall, which survived for $1 \mathrm{yr}$; elongation rate was calculated by dividing length increment over 1 yr by $365 \mathrm{~d}$. For comparison, a similar calculation was done for plants with stipes longer than $40 \mathrm{~cm}$.

At all 6 sites a minimum of 24 plants were harvested, once at Sites 4 to 6 , twice at Site 1 , and 3 times at Sites 2 and 3. At Sites 4 to 6 plants were selected from all size classes; at Sites 1 to 3 lines were placed between anchored pitons and all plants within a predetermined lateral distance (sufficient to obtain at least 30 plants) of these lines were harvested. Harvested plants were used to deternine plant density (after the collection area was measured), stipe length, presence of sporangia, biomass apportionment, and number of stipe rings (at 2 to $4 \mathrm{~cm}$ above the holdfast).

Stipe rings were counted by preparing 3 hand-cut sections from adjacent parts of the stipe, and examining them against a strong light. Rarely was the alternation of rings obscured when a dark ring separated into numerous fine dark and light ones on one or more radii; such individuals were not used. It is possible that 
the normally clear separation of rings observed in the Barkley Sound plants may not occur in areas with a less distinct seasonal pattern of, for example, light. Thus, M. Foster (pers. comm.) indicates that in Central California it is difficult to count the stipe rings.

Data gathered from harvested plants were also used to calculate correlations (Spain, 1982) between number of stipe rings and stipe length, and to calculate mean stipe length increment per ring (hereafter referred to as $M I / R_{i}$ column B in Table 1$)$. In the case of a linear correlation the mean annual stipe growth rate was divided by the $\mathrm{MI} / \mathrm{R}$ to provide an estimate of rings formed per year. For a curvilinear correlation the MI/R was based on data obtained from a size class distribution of harvested plants that was the same as that of the tagged plants.

At each of Sites 1 to 3 a series of 12 to $18 \mathrm{~m}$ long transects (point-centered quarter method, MuellerDombois and Ellenberg, 1974) were done between fixed end points (pitons). At random points (generated from a random number table) species, stipe length, and distance from the transect line to the holdfast were measured. These data were used as another measure of plant density, stipe size class distribution and, in conjunction with the stipe length/ring correlation, of age class distribution.

Sea urchin density was measured using $4 \mathrm{~m}$ long belt transects. Lead weighted line was placed on the bottom parallel to the depth contours, and all sea
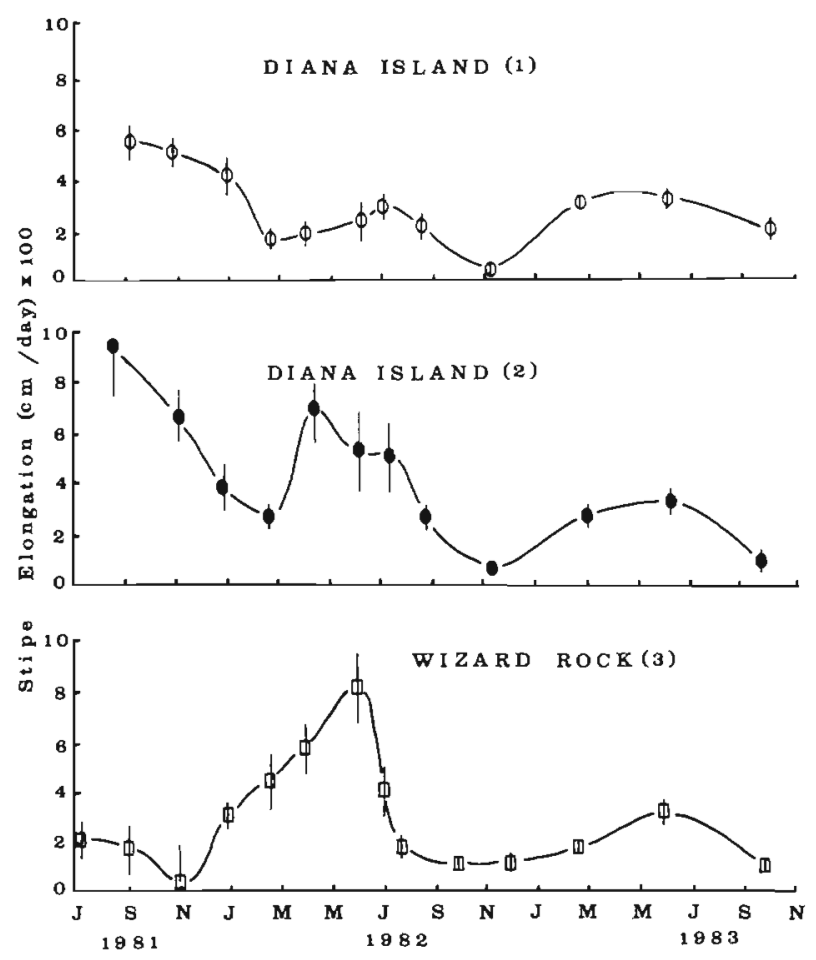

Fig. 2. Pterygophora californica. Mean growth rates $\left(\mathrm{cm} \mathrm{d}^{-1}\right.$ $\times 100)$ at 3 study sites. Error bars: 1 standard error urchins in eight $1 \mathrm{~m}$ by $30 \mathrm{~cm}$ blocks were counted. These transects were placed $5 \mathrm{~m}$ outside, $1 \mathrm{~m}$ outside and inside, and 3 to $4 \mathrm{~m}$ inside the study areas. In addition, qualitative observations were made on the occurrence of damage by urchins to the base of the stipes.

Data on nitrate and ammonium nitrogen concentrations were obtained from Dr. L. Druehl (pers. comm.). Water samples were collected 1981 to 1982 from 0 and $4 \mathrm{~m}$, at intervals ranging from 14 to $30 \mathrm{~d}$. The collection site (near Helby Island, Fig. 1) is approximately $1 \mathrm{~km}$ from both the Wizard and Diana study sites. The water samples were analyzed using an auto-analyzer.

Statistical tests were done as described in Sokal and Rohlf (1981), and evaluated at the 0.05 level of significance. Each test was preceded by an F-test to check for homogeneity of variance. When necessary, an appropriate transform was done to normalize the data. Unless indicated otherwise, an ANOVA (1-way) or t-test was used to test for differences among data sets. Standard errors of the means were calculated according to Gates (1960).

\section{RESULTS}

Mean depths of substrata below chart datum for Sites 1 to 3 are, respectively, $0.3,1.0$, and $1.4 \mathrm{~m}$; each mean depth differs significantly from the others. The upper portions of plants at Site 1 are periodically exposed to air, at tides lower than $+0.3 \mathrm{~m}$; such tides occur infrequently during daylight in Jun and Jul and, at night, in Nov and Dec.

The rate of stipe elongation of the tagged plants shows much variation between plants and, from 1981 to 1982 , between study sites. However, together with the data from 1982 to 1983, a pattern is apparent. Growth maxima generally occur in Mar-Jun and minima in Oct-Nov (Fig. 2). Due to the considerable inter-plant variation in stipe growth no significance can be assigned to differences between adjacent sampling dates but the maxima and minima are significantly different. Annual stipe elongation rates obtained from tagged plants surviving one year (Table 1) show significant differences between 1981-1982 and 1982-1983 within a site, and between Sites 1 and 2 for the first year only.

Stipe elongation rates of plants calculated to be $49 \mathrm{~d}$ old and growing on ropes were well in excess of those of tagged plants growing in the study sites. If the estimates of McKay (1933) for maturation rates of Pterygophora californica in culture are applicable to field material, then stipe elongation rates $( \pm 1$ standard error) of the $49 \mathrm{~d}$ old plants are approximately $0.13 \mathrm{~cm} \mathrm{~d}^{-1}$ ( $\left.\pm 0.008, \mathrm{~N}=60\right)$. This compares to 0.038 
Table 1. Pterygophora californica. Stipe elongation per year $(=\mathrm{A})$ (based on plants surviving 1 yr), per ring (=B, Ml/R) at 6 sites, ratio A : B (an estimate of the number of rings formed per year), and standard error (SE) of $N$ number of measurements

\begin{tabular}{|c|c|c|c|c|c|}
\hline Site, Year & A & $N$ & $\mathrm{~B}$ & $\mathrm{~N}$ & $\mathrm{~A} / \mathrm{B}$ \\
\hline & $\begin{array}{l}\text { Cm per year for } \\
\text { tagged plants }\end{array}$ & & $\begin{array}{l}\text { Cm per ring for } \\
\text { harvested plants }\end{array}$ & & \\
\hline \multicolumn{6}{|l|}{ Site 1} \\
\hline $1981-1982$ & $9.11 \pm 0.22$ & 27 & a $9.18 \pm 0.31$ & 46 & $0.99 \pm 0.006$ \\
\hline \multirow[t]{2}{*}{$1982-1983$} & $=\quad 6.23 \pm 0.56$ & 32 & $-\quad b 7.71 \pm 0.57$ & 26 & $-\quad 0.81 \pm 0.016$ \\
\hline & $\overline{\mathrm{X}}=7.67$ & & $\bar{X}=8.45$ & & $\bar{X}=0.91 \pm 0.023$ \\
\hline \multicolumn{6}{|l|}{ Site 2} \\
\hline $1981-1982$ & $18.18 \pm 1.71$ & 27 & $11.78 \pm 0.72$ & 27 & $1.54 \pm 0.025$ \\
\hline \multirow{2}{*}{$1982-1983$} & $6.25 \pm 0.70$ & 21 & b $8.91 \pm 0.45$ & 21 & $0.70 \pm 0.012$ \\
\hline & $\bar{x}=12.22$ & & $\bar{x}=10.34$ & & $\bar{X}=1.18 \pm 0.034$ \\
\hline \multicolumn{6}{|l|}{ Site 3} \\
\hline $1981-1982$ & $9.28 \pm 0.21$ & 27 & $9.15 \pm 0.36$ & 29 & $1.01 \pm 0.007$ \\
\hline \multirow[t]{2}{*}{$1982-1983$} & $5.43 \pm 0.47$ & 27 & ${ }^{b} 9.60 \pm 0.53$ & 24 & $0.56 \pm 0.007$ \\
\hline & $\bar{x}=7.36$ & & $\overline{\mathrm{X}}=9.37$ & & $\bar{X}=0.79 \pm 0.060$ \\
\hline Cable Beach & ---- & - & ${ }^{c} 11.83 \pm 3.34$ & 32 & ---- \\
\hline Execution Bay & --- & - & ${ }^{d} 13.80 \pm 4.40$ & 24 & ---- \\
\hline Birgey Bay & $\ldots-$ & - & e $9.18 \pm 1.92$ & 27 & ---- \\
\hline
\end{tabular}

$\mathrm{cm} \mathrm{d}^{-1}( \pm 0.73, \mathrm{~N}=12)$ for plants less than $25 \mathrm{~cm}$ tall growing during the same time period, and to annually based rates of $0.013 \mathrm{~cm} \mathrm{~d}^{-1}( \pm 0.002, \mathrm{~N}=14$ ) both for plants less than $25 \mathrm{~cm}$ tall and for those greater than $42 \mathrm{~cm}$ in height, growing at Wizard Rocks; data for the other 2 sites are comparable.

In contrast to the stipe, the sporophylls (lateral blades) and the apical blade are annual structures; however, all 3 grow rapidly in the Feb-Jun period (Fig. 2; Table 2). Despite their annual nature, sporophylls maintain a significant proportion of the dry weight biomass (Table 2). New sporophylls are rapidly formed beginning in Feb-Mar, remain sterile until Oct when sporangia form, and disintegrate in Feb-Mar of the following year. Based on in situ observations and data from harvested plants (Table 2) the biomass allocated to stipes and sporophylls is less at Site 3 than at Site 2 . However, the proportional allocations are similar. This is not true for the apical blade which, while similar in dry weight at the 2 sites, has a much larger proportional allocation at Site 3 .

The MI/R varied, but much less so than the annual growth rates. For plants at Site 2 the MI/R differed significantly from the other 2 sites, for 1982 . However, in 1983 collections these increments were statistically the same. Plants from Execution Bay and Cable Beach had the largest stipe increment per ring. Largely due to the variation in annual growth rate, the estimate of the number of rings formed per year also varies. However, in most cases the individual (and in all cases the average) (Table 1 ) is close to 1 and, when the standard
Table 2. Pterygophora californica. Biomass (mean dry weight, $\mathrm{g}$ and 1 standard error) of stipes, laterals, and blades, and proportion of each to total, at Sites 2 and 3, for 4 sampling dates. Data presented in chronological order by month, not year

\begin{tabular}{|c|c|c|c|c|}
\hline \multicolumn{5}{|c|}{ Diana (Site 2) } \\
\hline Date & $N$ & Stipe & Laterals & Blade \\
\hline Dec 1981 & $\begin{array}{l}24 \\
\text { Ratio }\end{array}$ & $\begin{array}{c}43.4 \pm 5.7 \\
(0.55)\end{array}$ & $\begin{array}{c}35.0 \pm 6.0 \\
(0.44)\end{array}$ & $\begin{array}{c}0.40 \pm 0.06 \\
(0.005)\end{array}$ \\
\hline Jan 1984 & $\begin{array}{l}29 \\
\text { Ratio }\end{array}$ & $\begin{array}{c}52.5 \pm 5.2 \\
(0.76)\end{array}$ & $\begin{array}{c}16.0 \pm 1.5 \\
(0.23)\end{array}$ & $\begin{array}{c}0.37 \pm 0.03 \\
(0.005)\end{array}$ \\
\hline Feb 1983 & $\begin{array}{l}29 \\
\text { Ratio }\end{array}$ & $\begin{array}{c}66.8 \pm 7.7 \\
(0.73)\end{array}$ & $\begin{array}{c}23.9 \pm 2.7 \\
(0.26)\end{array}$ & $\begin{array}{c}0.42 \pm 0.04 \\
\quad(0.005)\end{array}$ \\
\hline Apr 1982 & $\begin{array}{l}30 \\
\text { Ratio }\end{array}$ & $\begin{array}{c}55.5 \pm 6.0 \\
(0.58)\end{array}$ & $\begin{array}{c}34.6 \pm 3.5 \\
\{0.36\}\end{array}$ & $\begin{array}{c}4.90 \pm 0.40 \\
(0.052)\end{array}$ \\
\hline \multicolumn{5}{|c|}{ Wizard Rocks (Site 3) } \\
\hline Dec 1982 & $\begin{array}{l}30 \\
\text { Ratio }\end{array}$ & $\begin{array}{c}5.5 \pm 0.60 \\
(0.51)\end{array}$ & $\begin{array}{c}4.7 \pm 0.95 \\
(0.44)\end{array}$ & $\begin{array}{c}0.61 \pm 0.10 \\
(0.057)\end{array}$ \\
\hline Jan 1984 & $\begin{array}{l}30 \\
\text { Ratio }\end{array}$ & $\begin{array}{c}22.4 \pm 1.9 \\
(0.66)\end{array}$ & $\begin{array}{c}11.0 \pm 1.5 \\
(0.32)\end{array}$ & $\begin{array}{c}0.52 \pm 0.06 \\
(0.015)\end{array}$ \\
\hline Feb 1983 & $\begin{array}{l}30 \\
\text { Ratio }\end{array}$ & $\begin{array}{c}21.1 \pm 4.0 \\
(0.65)\end{array}$ & $\begin{array}{c}10.6 \pm 2.3 \\
(0.33)\end{array}$ & $\begin{array}{c}0.54 \pm 0.07 \\
(0.017)\end{array}$ \\
\hline May 1982 & $\begin{array}{l}30 \\
\text { Ratio }\end{array}$ & $\begin{array}{c}13.7 \pm 3.1 \\
(0.48)\end{array}$ & $\begin{array}{c}11.2 \pm 2.0 \\
(0.39)\end{array}$ & $\begin{array}{c}3.6 \pm 0.35 \\
(0.125)\end{array}$ \\
\hline
\end{tabular}

errors are taken into account, include 1 (but not 2) ring per year.

Data from plants harvested at all 6 sites show a high correlation ( $R=0.8-0.9$ ) between number of stipe rings and stipe length. For Sites 1 and 3 a straight line 
correlation was found $(y=0.68+0.096 \mathrm{x}$, and $\mathrm{y}=$ $0.046+0.109 x_{i} y=$ number of rings) and for Site $2 \mathrm{a}$ slightly curvilinear one $\left(y=a /\left(1+b x^{n} ; a=250, b=\right.\right.$ 486, $n=-0.584)$; these equations were calculated for data from Apr-May, 1982. Since 1 stipe ring is formed per year at these study sites the above correlations, in addition to the actual ring counts from harvested plants, were used to estimate the age-class distributions (Fig. 3) for plants at Sites 1 to 3.

Both stipe lengths and attrition rates vary at the 3 primary study sites. A significant difference exists between stipe lengths at Sites 1 and 2 . Over the 2 sampling years plants 2 yr old and older at Sites 1 to 3 have attrition rates of 32,32 , and $21 \%$, respectively.

Based on data from transect lines Site 3 has the greatest overall density of kelps (Eisenia arborea, Laminaria setchellii, Pterygophora californica) (Table 3) but only at the lower extent of the site; it has the lowest density of $P$. californica thalli.

Sea urchins are common outside the kelp beds (Table 4) on algal-crust covered pavement and rock at Sites $2-3$, but are uncommon within the kelp communities. Observations made at the study sites show that Pterygophora californica stipe bases were often grazed at Sites 2 and 3, but not at Site 1.

Analysis of the nitrogen data showed significant differences in concentrations at both 0 and $4 \mathrm{~m}$ between the period of greater stipe, blade, and sporophyll growth (Feb-Jun) and reduced growth (Oct-Dec). For ammonium the mean concentration ( $\mu \mathrm{g}$ at $\left.1^{-1}, \pm 1 \mathrm{SE}\right)$ for Feb-Jun was $0.55( \pm 0.07, \mathrm{~N}=15)$ and 0.87 ( $\pm 0.09, N=16$ ) for 0 and $4 \mathrm{~m}$, respectively, and $1.86( \pm 0.29, \mathrm{~N}=7)$ and $2.03( \pm 0.20, \mathrm{~N}=6)$ for
Oct-Dec. Similarly, for nitrate nitrogen the data are 3.3 ( $\pm 0.87, N=20), 4.97( \pm 0.88, N=20)$, and 8.2 $( \pm 1.44, N=9), 8.1( \pm 1.38, N=11)$, respectively.
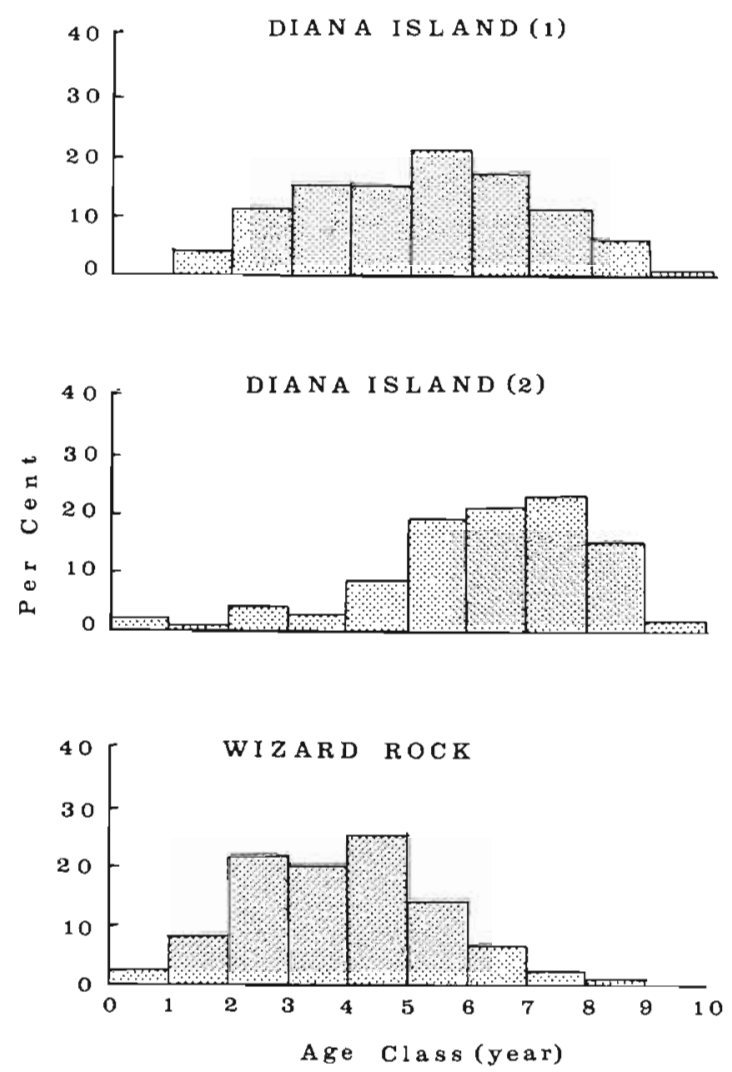

Fig. 3. Pterygophora californica. Age class distribution for Dec, 1981, at 3 study sites: Diana Island shallow (1) ( $N=95)$, Diana Island deep (2) $(\mathrm{N}=313)$, Wizard Rock (3) $(\mathrm{N}=167)$

Table 3. Plant density (plants $\mathrm{m}^{-2}$ ) at 3 study sites at various sampling dates, and mean stipe length $(\mathrm{cm})$. Pt $=$ Pterygophora californica, Lam = Laminaria setchellii, Eis = Eisenia arborea. $\mathrm{SE}=$ standard error; $\mathrm{N}=$ number of measurements for P. californica

\begin{tabular}{|c|c|c|c|c|c|c|c|}
\hline \multicolumn{8}{|c|}{ Species } \\
\hline Site & Date & $\mathrm{Pt}$ & Lam & Eis & Others & Stipe length (SE) & $\mathrm{N}$ \\
\hline \multicolumn{8}{|l|}{ Diana } \\
\hline Site 1 & Nov 20,1982 & 14.5 & 0.0 & 0.0 & 2.1 & $46 \pm 3.9$ & 35 \\
\hline \multirow[t]{5}{*}{ Site 2} & Jun 17,1981 & 8.0 & 0.0 & 0.0 & 0.0 & $69 \pm 4.0$ & 59 \\
\hline & Aug 20, 1981 & 6.8 & 0.0 & 0.0 & 1.1 & $64 \pm 4.2$ & 70 \\
\hline & Dec 13,1981 & 5.4 & 0.0 & 0.0 & 0.2 & $82 \pm 3.7$ & 60 \\
\hline & Apr 19,1982 & 6.7 & 0.0 & 0.0 & 0.0 & $92 \pm 5.2$ & 36 \\
\hline & Feb 5,1983 & 6.7 & 0.0 & 0.0 & 1.0 & $64 \pm 5.4$ & 37 \\
\hline \multicolumn{8}{|c|}{ Wizard } \\
\hline \multirow[t]{5}{*}{ Site 3} & Jun 16,1981 & 1.5 & 7.2 & 2.7 & 0.4 & $34 \pm 3.6$ & 11 \\
\hline & Sep 26, 1981 & 2.0 & 6.6 & 4.2 & 0.0 & $34 \pm 2.7$ & 9 \\
\hline & Sep 27, 1981 & 2.7 & 3.9 & 9.0 & 0.0 & $42 \pm 5.5$ & 9 \\
\hline & May 5, 1982 & 2.0 & 0.6 & 0.2 & 0.0 & $36 \pm 3.5$ & 12 \\
\hline & Sep 2,1982 & 2.7 & 3.9 & 10.2 & 0.0 & $42 \pm 4.0$ & 9 \\
\hline
\end{tabular}


Table 4. Strongylocentrotus franciscanus. Sea urchin density (urchins $\mathrm{m}^{-2} \pm 1$ standard error) measured $5 \mathrm{~m}$ outside $(=5 \mathrm{~m}$ out), $1 \mathrm{~m}$ outside (= $1 \mathrm{~m}$ out), $1 \mathrm{~m}$ inside $(=1 \mathrm{~m}$ in), and $5 \mathrm{~m}$ inside $(=5 \mathrm{~m} \mathrm{in}$ ) at 2 study sites. $\mathrm{N}=4$ for both sites

\begin{tabular}{|c|c|c|c|c|c|c|c|c|}
\hline \multirow{2}{*}{$\underbrace{\text { Date and place }}_{\text {Diana (Site 2) }}$} & \multicolumn{2}{|c|}{$5 \mathrm{~m}$ out } & \multicolumn{2}{|c|}{$1 \mathrm{~m}$ out } & \multicolumn{2}{|c|}{$1 \mathrm{~m}$ in } & \multicolumn{2}{|c|}{$5 \min$} \\
\hline & $\overline{\mathrm{x}}$ & $\mathrm{SE}$ & $\bar{x}$ & SE & $\overline{\mathrm{x}}$ & SE & $\overline{\mathrm{x}}$ & SE \\
\hline Dec 13, 1981 & 0.5 & \pm 0.45 & 0.3 & \pm 0.25 & 0.6 & \pm 0.25 & 0.3 & \pm 0.35 \\
\hline Jun 15,1982 & 1.5 & \pm 0.25 & 1.0 & \pm 0.6 & 1.4 & \pm 0.65 & 0.0 & - \\
\hline Dec 28,1982 & 1.1 & \pm 0.3 & 1.1 & \pm 0.5 & 0.1 & \pm 0.2 & 0.0 & - \\
\hline \multicolumn{9}{|l|}{ Wizard (Site 3) } \\
\hline Sep 27, 1981 & 11.0 & \pm 3.0 & 12.7 & \pm 5.0 & 0.0 & - & 0.0 & - \\
\hline Nov 27,1981 & 3.0 & \pm 1.0 & 6.8 & \pm 1.6 & 0.0 & - & 0.0 & - \\
\hline Jan 28,1982 & 0.5 & \pm 0.25 & 1.1 & \pm 0.4 & 0.0 & - & 0.0 & - \\
\hline Mar 20,1982 & 2.6 & \pm 1.3 & 5.0 & \pm 1.4 & 0.0 & - & 0.0 & - \\
\hline May 26,1982 & 2.0 & \pm 0.95 & 3.4 & \pm 0.8 & 0.0 & - & 0.0 & - \\
\hline Aug 29,1982 & 2.4 & \pm 1.3 & 6.0 & \pm 1.1 & 0.0 & - & 0.0 & - \\
\hline Dec 29, 1982 & 2.4 & \pm 1.0 & 7.5 & \pm 1.4 & 0.0 & - & 0.0 & - \\
\hline
\end{tabular}

\section{DISCUSSION}

Despite differences in rates of stipe growth, and some displacement of growth maxima and minima at the different sites and over successive years, patterns can be discerned. Stipes show a similar periodicity in growth, and age-class distribution estimates for Pterygophora californica yield similar results for all 3 main study sites.

The rates of stipe elongation varied between sites and over time. For example, in 1982-1983 plants at the 3 primary study sites all had comparatively low growth rates compared to the previous year. This conclusion is strengthened by the fact that the 1982-1983 rate at all 3 sites is also below the MI/R (which can be considered a life time average). The growth maximum beginning in (Feb) Mar is similar to that reported for other kelp species (Chapman and Craigie, 1977; Kain, 1979). The decline in stipe growth from (usually) Oct-Dec coincides with the onset of reproduction in Oct, and maximum stipe elongation occurs when plants are nonreproductive.

Nitrogen is probably important for growth of Pterygophora californica but, based on this study, rapid growth does not coincide with times when nitrogen is most available in the water. Total inorganic nitrogen was found by Druehl (1980 and pers. comm.) to vary both seasonally and with depth at a location near the study sites. It is likely that $P$. californica is able to store nitrogen when this nutrient is more abundant, for use when it is less available. As a result, growth can be uncoupled from nitrogen concentrations in the water, as is also known to occur for other species in the Laminariales (Chapman and Craigie, 1977; Schmitz, 1981).

The average stipe length within Sites 1 to 3 varied considerably but, despite this, plants at Site 1 were significantly shorter than the adjacent, but deeper, plants at Site 2. Three hypotheses which could account for these differences are: (1) plants at Site 1 have a higher rate of attrition and thus a younger (and therefore shorter) population; (2) plants at Site 1 have a higher proportion of individuals in younger age class-

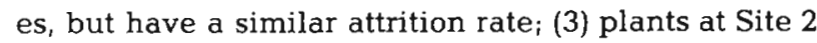
grow more rapidly. Since attrition rates were found to be similar for Sites 1 and 2, hypothesis (1) is falsified. However, Site 1 has a higher proportion of plants in the younger age classes, resulting in more smaller plants, and this site also has a lower mean growth rate. Thus, both hypotheses (2) and (3) are supported and both factors probably contribute to the presence of a population with shorter stipes at Site 1 . The same combination of factors is probably responsible for the shorter plants found at Site 3 (compared to Site 2) although here the difference in length is not statistically significant.

The fact that Site 1 encounters more turbulence, and is at a more shallow depth, than Site 2 also makes the short stipe phenomenon consistent with several reports in the literature. Gerard and Mann (1979, and others cited therein) report that individuals of Laminaria growing in exposed sites have shorter stipes than those in more sheltered locations. Additional factors which may limit stipe growth in plants at Site 1 are their exposure to air during some tidal cycles, and the operation of a phytochrome effect similar to that postulated by Duncan and Foreman (1980) for Nereocystis luetkeana.

In order to obtain an estimate of age-class distribution at each site it was first necessary to determine the periodicity of stipe-ring formation. The general procedure has been outlined under 'Results', but some addi- 
tional comments are necessary. The average stipe length increment per ring can be obtained by dividing the stipe length by the number of rings. If the stipe length to ring correlation is close to a linear one (as is the case for Sites 1 and 3), a constant length increment per ring is indicated and, by dividing the in situ measured annual stipe length increment by the $M I / R$, an estimate of the number of rings formed per year is obtained. If the relation is curvilinear (as for Site 2) then stipe length increment varies with each ring formed. In this latter case it is essential that stipe length increment data are obtained from plants with the same size-class distribution as those from which the in situ growth measurements were made.

When the above procedures were applied, plants at all 3 primary study sites were found to have, on average, annual rings; this is in agreement with the reports of others for different species, and with the speculation for this species by earlier authors. Also, since the rings are most likely formed by alternating periods of rapid and slow growth, the annual growth cycle of the stipe shown in Fig. 2 supports annual ring formation.

It can be argued, however, that smaller (= younger) plants grow more rapidly than older (= larger) plants, and that smaller plants may also form more than 1 ring $\mathrm{yr}^{-1}$. If this were true then one would still obtain the same stipe increment per ring, but the age of plants estimated from size correlations would be wrong; as a logical consequence it would aiso follow that the growth rate of small plants would be greater than that of larger ones. The data show that small plants growing in situ have stipe elongation rates similar to those of larger plants, but that small plants growing on artificial substratum (and thus away from the influence of larger plants) have growth rates greater than those of plants in a natural community. Also, when the annual growth rate of small tagged plants is taken into account, it is clear that these also form only 1 dark and 1 light ring $\mathrm{yr}^{-1}$.

Using the above information the age-class distributions were determined for Pterygophora californica at each site. The distributions were generally similar for all 3 sites, in that each had a low proportion of plants in the youngest and oldest age classes. While working at the study areas many young plants (aged 0 to $1 \mathrm{yr}$ ) were observed by Mar at the periphery of the established populations, or in clearings within it, but these had largely disappeared by Oct-Nov. If the young plants continue to exhibit such a low rate of survival, the population density will decline. However, other events may intervene; for example, attrition of older plants due to storms (Cowen et al., 1982) and grazing by sea urchins (Leighton et al., 1966; Foreman, 1977; Pearse and Hines, 1979) can provide suitable conditions for growth of young plants of $P$. californica.
Numerous authors have shown (tor review see Cowen et al., 1982) that sea urchins can limit the extent of a kelp community or may remove it entirely. Pace (1981) found that at Wizard Rocks (here, Site 3) the sea urchins determine the lower limits of the Pterygophora californica population; intensive grazing removed most algae, and exclusion of sea urchins resulted in heavy settlement of young $P$. californica. Furthermore, once a $P$. californica canopy is established it is rare for its juvenile sporophytes to mature, as concluded by Pearse and Hines (1979) based on their studies in California, and by the data in this paper. Such events would produce an age distribution similar to that found at my study sites.

While the attrition rates for plants at Sites 1 and 2 are the same, the reasons for the loss of plants are probably different. Since neither sea urchins nor grazing damage was ever observed at Site 1 the major cause of attrition at this site is probably turbulence. In contrast urchins, and stipe damage caused by them, were common at Sites 2 and 3 and these, plus damage due to turbulence, are the likely causes of attrition of Pterygophora californica at this site.

Pterygophora californica is an important constituent of some subtidal communities in British Columbia, Canada. This research has shown that at 3 study sites an annual periodicity in stipe growth occurs, that stipe elongation is least during the reproductive period of the sporophyte, and that growth rings form annually. Proportional allocation of stipe and sporophyll biomass is similar for $P$. californica at Sites 2 and 3 despite differences in total biomass. However, the biomass of the apical blade is proportionately greater in the Wizard Rocks site which has smaller plants for a given age. Although the age distribution of $P$. californica is similar at the 3 sites, with a low proportion of young and old plants, the dominant age class varies between sites. Since stipe growth rate varies annually and from site to site, it is essential to establish a stipe length to ring correlation at each site before population age structure can be determined.

Acknowledgements. Herb Vandermeulen and Terrie Klinger were of great assistance while diving. I also appreciate the work of $\mathrm{M}$. Foster in reviewing the original manuscript.

\section{LITERATURE CITED}

Canadian Hydrographic Service (1982). Canadian tide and current tables, Vol. 5. Fisheries and Oceans, Ottawa

Chapman, A. R. O., Craigie, J. S. (1977). Seasonal growth in Laminaria longicruris: relations with dissolved inorganic nutrients and internal reserves of nitrogen. Mar. Biol. 40: 197-205

Cowen, R. K., Agegian, C. R., Foster, M. S. (1982). The maintenance of community structure in a central California kelp forest. J. exp. mar. Biol. Ecol. 64: 189-201 
Coyer, J. A., Zaugg-Haglund, C. (1982). A demographic study of the elk-kelp, Pelagophycus porra (Laminariales, Lessoniaceae), with notes on Pelagophycus $\times$ Macrocystis hybrids. Phycologia 21: 399-407

Druehl, L. (1980). The development of an edible kelp culture technology for British Columbia. II. Second Annual Report. Fisheries Development Report No. 26. Marine Resources Branch, Victoria, B.C., p. 1-43

Duncan, M. J., Foreman, R. E. (1980). Phytochrome mediated stipe elongation in the kelp Nereocystis (Phaeophyceae) J. Phycol. 16: 138-142

Foreman, R. E. (1977). Benthic community modification and recovery following intensive grazing by Strongylocentrotus droebachiensis. Helgoländer Meeresunters. 30: 468-484

Frye, T. C. (1918). The age of Pterygophora californica. Publs Puget Sound mar. biol. Stn 2: 65-71

Gates, F. (1960). Sampling methods for census and surveys (esp. p. 196-201). Hafner Publ. Co., New York

Gunnill, F. C. (1980). Demography of the intertidal brown alga Pelvetia fastigiata in southern California, U.S.A. Mar. Biol. 59: 169-179

Gerard, V. A., Mann, K. H. (1979). Growth and production of Laminaria longicruris (Phaeophyta) populations exposed to different intensities of water movement. J. Phycol. 15: $33-41$

Kain, J. M. (1971). Synopsis of biological data on Laminaria hyperborea. F.A.O. Fish. Syn. No. 87

Leighton, D. L., Jones, L. G., North, W. J. (1966). Ecological relationships between giant kelp and sea-urchins in southern California. In: Young, E. G., McLanghlin, J. M. (ed.) Proceedings of the Fifth International Seaweed Symposium, Halifax, p. 141-153

MacMillan, C. (1902). Observations on Pterygophora. Minn. bot. stud. 2: 723-741

McKay, H. H. (1933). The life-history of Pterygophora californica Ruprecht. Univ. Calif. Publ. Bot. 17: 111-148

Mueller-Dombois, D., Ellenberg, H. (1974). Aims and methods of vegetation ecology. John Wiley and Sons, Inc., Chichester, p. 1-547

Novaczek, I. (1981). Stipe growth rings in Ecklonia radiata (C. Ag.) J. Ag. (Laminariales). Br. phycol. J. 16: 363-371

Pace, D. (1981). Kelp community development in Barkley Sound, British Columbia following sea urchin removal. In: Fogg, G. E., Jones, W. E. (ed.) Proceedings of the 8th International Seaweed Symposium Bangor, The Marine Science Laboratories, Menai Bridge, p. 457-463

Pearse, J. S., Hines, A. H. (1979). Expansion of a central California kelp forest following mass mortality of sea urchins. Mar. Biol. 51: 83-89

Ruprecht, F. J. (1848). Bemerkungen über den Bau und das Wachstum einiger großen Algen-Stämme. Mem. Acad. Imp. Sci. Nat. Ptersb. 6: 64-70

Schmitz, K. (1981). Translocation. In: Lobban, C., Wynne, M. (ed.) The biology of seaweeds. Botanical Monographs 17 : $1-786$

Sokal, R, Rohlf, F. J. (1981). Biometry. W. H. Freeman and Co., San Francisco

Spain, J. D. (1982). BASIC Microcomputer models in biology. Addison Wesley Publ. Comp., Reading, Massachusetts

This paper was presented by Professor J. S. Pearse; it was accepted for printing on April 23, 1984 